\title{
Investigation of the Relationship between Breast Cancers and HPVs
}

\author{
Mervat Saeed $^{1, *}$, Yasemin Zer ${ }^{1}$, Zehra Bozdağ ${ }^{2}$ \\ ${ }^{1}$ Department of Medical Microbiology, Institute of Medical Sciences, University of Gaziantep, Turkey \\ ${ }^{2}$ Department of Pathology, Gaziantep University Hospital, Turkey
}

Copyright $\bigcirc 2018$ by authors, all rights reserved. Authors agree that this article remains permanently open access under the terms of the Creative Commons Attribution License 4.0 International License

\begin{abstract}
High-risk human papillomaviruses (HR-HPVs) have been implicated in the aetiology of a variety of human cancers, including cervical, colorectal, and head and neck (HN); also, (HPVs) may be important risk factors for breast carcinogenesis and metastasis. Previous studies that evaluated the prevalence of HPVs in breast cancer have generated considerable controversy. Based on this hypothesis, we aimed to investigate the prevalence of HPV infection in invasive breast cancer tissues. Our study included 80 paraffin blocks taken from breast cancerous tissue specimens of Turkish female patients and 13 controls (cervical cancerous tissue specimens) in Research and Practice Hospital- Sahinbey -Gaziantep University, using PCR (HPV Genotypes 14 Real-TM Quant / Italy) to detect the HR-HPV DNA. In our results: HR-HPV DNA was evidenced in $(10 \%)$ of the breast cancer and in $(92.3 \%)$ of the controls $(\mathrm{p}<0.05)$. HPV (45-56-68) were the most prevalent genotypes in breast cancer cases. Also HPV co-infection was high $(75 \%)$ in positive breast cancerous samples. Our data propose Human papilloma viruses may play a role as a possible causal relationship, or mediation or even as a cofactor in the development of some types of breast cancer, this still needs to be confirmed by prospective studies.
\end{abstract}

Keywords HR-HPV, Breast Cancer, Multiple Real Time PCR

\section{Introduction}

Breast cancer is the most commonly diagnosed malignancy in women. It is estimated that 1.7 million new cases were diagnosed in 2012, representing $11.9 \%$ of all cancers diagnosed worldwide in both genders, and $25 \%$ of those diagnosed in women [1]. Analyses using Globocan 2012 data have reported that one out of every 25 women in Turkey will develop breast cancer in some period of their lives [2].

Although it is well-known that multiple risk factors are associated with breast cancer development, in most cases the initiating cause has not been identified. This has led to studies to identify new factors related to this neoplasia. Infectious agents have been implicated, as either direct carcinogens or promoters. In particular, Human Papillomaviruses (HPVs) are recognized as carcinogenic agents in breast cancer in humans [3]. The immortalization of HPV 16 and 18 genomes in a group of human breast cells after the infection may cause breast cancer associated with HPV [4]. The current published data on HPV and breast cancer are very contradictory, since the reported prevalence of HPV ranges from $0 \%$ to $86.21 \%$ in breast cancer tissue samples [1].

The HPVs belong to a large family of common viruses that infect cutaneous and mucosal epithelial surfaces (skin, genital) and cause both benign and malignant hyper-proliferative lesions [5, 6, 7].

Although about $90 \%$ of HPV infections are asymptomatic and are usually cleared spontaneously by the immune system within two years, albeit after a long delay period, persistence of HPV can cause progression to malignant disease in the presence of appropriate risk factors. For example, infection of the cervix with "high risk" HPV types 16 and 18 is the initiating event in $90 \%$ of cervical cancer cases [3].

Regardless, while the body is working to get the infection under control, the HPV can spread through sexual means and by skin to skin contact $[8,9]$. High risk HPV types are regarded as the most important aetiological factor for cervical cancer $[8,10]$. HPVs have also been found to cause close to half of all vaginal, penile, anal, and oral cancers [9]. In addition, the presence of high-risk HPVs serve as prognostic factors in early-stage cervical, colorectal and HN cancers, and are associated with vascular invasion, lymph node metastases and tumour size [11,12-13]. The E6 and E7 onco-proteins of high-risk HPVs, which are constitutively expressed in these cancers, inactivate $\mathrm{p} 53$ and $\mathrm{pRb}$ tumour suppressors, respectively [14]. This results in genomic instability and has been implicated in the progression of normal cells into cancer cells [7]. 
Investigating a relationship between HPV and breast cancer is a valid hypothesis for a number of reasons. The exposure of the mammary ducts to the external environment via the nipple areola complex could provide an entry point for HPV infection. Also, most breast cancers originate from mammary duct epithelia [15].

Specifically, this study aims to determine the presence of High-risk (HR) HPV (16, 18, 31, 33, 35, 39, 45, 51, 52, $56,58,59,66$ and 68) genotypes in samples obtained from breast cancers at the University Hospital of Gaziantep (Turkey) using Real Time (RT) PCR approaches.

\section{Materials and Methods}

\subsection{Method}

In Gaziantep University, Faculty of Medicine, Şahinbey - Research and Practice Hospital, 80 paraffin blocks taken from breast cancer tissues of female patients with aged (27-86) years which were diagnosed, fixed with formalin (buffered neutral aqueous 10\% solution) and stored as an archive material in Pathology Laboratory during (2014-2017), were used for this study. Using of these specimens and data in research was approved by the Ethics Committee of Gaziantep University. In the study, paraffin blocks were melted and examined by molecular method (PCR) to determine the DNA of high risk HPV genotypes $(16,18,31,33,35,39,45,51,52,56,58,59,66$ and 68). We also examined 13 cases of cervical cancer as a control for this study.

\subsection{Deparaffinised and Tissue Protocol}

1. The paraffin embedded tissue sample was cut into thin pieces. $20-30 \mathrm{mg}$ of sample was placed into the bottom of $1.5 \mathrm{ml}$ nuclease-free microcentrifuge tube.

2. $1 \mathrm{ml}$ of xylene was added, mixed by vortex and incubated at room temperature for 10 minutes.

3. Centrifuge at $14.000 \mathrm{x}$ rpm for 3 minutes was used. Then supernatant was removed.

4. 2-3 steps were repeated once more.

5. $1 \mathrm{ml}$ of ethanol $(96=100 \%)$ was added, and mixed by vortex. Then centrifuge at 14,000 x rpm for 3 minutes was applied. The supernatant was removed.

6. $1 \mathrm{ml}$ of ethanol (90\%) was added, and mixed by vortex. Then centrifuge at $14.000 \mathrm{x} \mathrm{rpm}$ for 3 minutes and then supernatant was removed.

7. $1 \mathrm{ml}$ of ethanol $(70 \%)$ was added, mixed by vortex. Then centrifuge at $14.000 \mathrm{x} \mathrm{rpm}$ for 3 minutes was applied and the supernatant was removed.

8. The precipitate was incubated at room temperature for 10 minutes to dry.

9. Protinase $\mathrm{K}$ was diluted with $5.5 \mathrm{ml}$ re-suspension buffer.
10. $1200 \mu \mathrm{L}$ ATL (Tissue Lysis Buffer) was added to 2 $\mathrm{ml}$ sample tube containing the tissue, $60 \mu \mathrm{L}$ Protinease $\mathrm{K}$ was added then the mixture was incubated for 2 hours at $56{ }^{\circ} \mathrm{C}$ with occasional mixing by vortex, after 2 hours the sample spin centrifuge was performed.

11. $400 \mu \mathrm{l}$ of the supernatant liquid was introduced into the sample tube. Then the sample tube was installed on the device.

High-risk HPV genotypes (types 16, 18, 31, 33, 35, 39 , $45,51,52,56,58,59,66$ and 68) were investigated by molecular method using the required amount of pure DNA according to the protocol from the purified specimen. Real time multiplex PCR (kit, HPV Genotypes 14 Real-TM Quant / Italy) was used for the detection.

\section{3. "HPV Genotypes 14 Real-TM Quant"}

\subsubsection{Kit contents}

\section{Materials Provided}

"HPV Genotypes 14 Real-TM Quant":

- PCR-mix-1 “16-18-31-IC”, 4 x 0,3 ml (blue cap)

- $\quad$ PCR-mix-1 “39-45-59-IC”, 4 x 0,3 ml (pink cap)

- $\quad$ PCR-mix-1 “33-35-56-68”, 4 x 0,3 ml (green cap)

- $\quad$ PCR-mix-1 “51-52-58-66”, 4 x 0,3 ml (orange cap)

- $\quad$ PCR- buffer-FRT, 4 x 0,6 ml

- Hot Start DNA Polymerase, 4 x 0,06 ml

- $\quad$ Negative Control* ${ }^{*}, 2 \mathrm{ml}$;

Standards:

- $\quad \mathrm{K} 1$ “16-18-31-IC”, 0,2 ml (mix HPV DNA C+ 16, 18,31 and human DNA) - 1.000.000 GE/ml

- $\quad \mathrm{K} 2$ “16-18-31-IC", 0,2 ml (mix HPV DNA C+ 16, 18,31 and human DNA) - $1.000 \mathrm{GE} / \mathrm{ml}$

- K1 “39-45-59-IC”, 0,2 ml (mix HPV DNA C+ 39, 45, 59 and human DNA) - 1.000.000 GE/ml

- $\quad \mathrm{K} 2$ “39-45-59-IC”, 0,2 ml (mix HPV DNA C+ 39, 45,59 and human DNA) $-1.000 \mathrm{GE} / \mathrm{ml}$

- $\quad \mathrm{K} 1$ “33-35-56-68”, 0,2 ml (mix HPV DNA C+ 33, $35,56,68)-1.000 .000 \mathrm{GE} / \mathrm{ml}$

- $\quad \mathrm{K} 2$ “33-35-56-68”, 0,2 ml (mix HPV DNA C+ 33, $35,56,68)-1.000 \mathrm{GE} / \mathrm{ml}$

- $\quad \mathrm{K} 1$ “51-52-58-66", 0,2 ml (mix HPV DNA C+ 51, $52,58,66)-1.000 .000 \mathrm{GE} / \mathrm{ml}$

- $\quad \mathrm{K} 2$ “51-52-58-66”, 0,2 ml (mix HPV DNA C+ 51, $52,58,66)-1.000 \mathrm{GE} / \mathrm{ml}$

\subsection{2. "HPV Genotypes 14 Real-TM Quant" kit Protocol}

- $\quad$ Prepare required quantity of PCR tubes according to assay type

- Quantitative analysis: 4 tubes for each clinical sample (half strip), 4 tubes for K1 standards and 4 tubes for K2 standards (total 1 strip), 4 tubes for Neg. Control (half strip) 
- Qualitative analysis: 4 tubes for any clinical sample (half strip), 4 tubes for standard K2 (half strip) and 4 tubes for Neg. Control (half strip)

- Prepare Mix for 132 reactions: add into the tube with PCR-buffer-FRT $60 \mu \mathrm{l}$ of Hot Start DNA Polymerase Carefully vortex the tube. This mix is stable for 3 months at $+4^{\circ} \mathrm{C}$.

- 3. Prepare for each PCR-mix-1 one new tube and add for each sample $10 * \mathrm{~N}+3(+2$ for qualitative analysis) $\mu \mathrm{l}$ of PCR-mix-1 and $5 * \mathrm{~N}+3$ (+2 for qualitative analysis) of Mix (PCR-buffer-FRT with Hot Start DNA Polymerase). For example, for quantitative analysis of 8 clinical samples prepare $110 \mu \mathrm{l}$ of every PCR-mix-1 $(10 *[8+3])$ and add $55 \mu 1$ of Mix (see table 2 and 3 ).

- $\quad 4$. Add $15 \mu$ l of Reaction Mix into each tube. (every sample has to be tested in 4 tubes): add in the first line of tubes $15 \mu \mathrm{l}$ of mix " $16,18,31, \mathrm{IC}$ ", in the second line $15 \mu \mathrm{l}$ of mix " $39,45,59, \mathrm{IC}$ ", in the third $15 \mu \mathrm{l}$ of mix " $33,35,56,68$ ", in the fourth $15 \mu \mathrm{l}$ of mix " $51,52,58,66$ ".

- 5. Add $10 \mu \mathrm{l}$ of extracted DNA sample to appropriate tube.

- 6. Prepare for each panel controls and standards:

- add $10 \mu \mathrm{l}$ of DNA extracted from Negative Control to the tubes of strip $\mathrm{N}^{\circ} 16$;

- $\quad$ add $10 \mu \mathrm{l}$ of each $\mathrm{K} 1$ to the tubes of strip $\mathrm{N}^{\circ} 17$ (required for quantitative analysis only);

- $\quad$ add $10 \mu \mathrm{l}$ of each $\mathrm{K} 2$ to the tubes of strip $\mathrm{N}^{\circ} 18$;

Table 2. Distribution of patients according to cancer types

\begin{tabular}{|c|c|c|}
\hline Cancer types & $\mathrm{n}$ & (\%) \\
\hline Cervical cancer & 13 & 14.0 \\
\hline Breast invasive ductal carcinoma & 70 & 75.3 \\
\hline Breast invasive lobular carcinoma & 10 & 10.8 \\
\hline Total & 93 & 100 \\
\hline
\end{tabular}

Table 3. Identification of HR-HPV DNA in breast and cervical cancerous tissue specimens

\begin{tabular}{|c|c|c|c|c|c|c|}
\hline \multirow{2}{*}{ Cancer type } & \multicolumn{2}{|c|}{ HR-HPV-DNA } & \multirow{2}{*}{ Total } & \multirow{2}{*}{$\chi^{2}$} & P \\
\cline { 2 - 5 } & Negative & Positive & & & \\
\hline \multirow{2}{*}{$\begin{array}{c}\text { Cervical } \\
\text { cancer }\end{array}$} & $\mathrm{n}$ & 1 & 12 & 13 & & \\
\cline { 2 - 5 } & $\%$ & 7.7 & 92.3 & 100.0 & \multirow{2}{*}{78.300} & 0.000 \\
\hline $\begin{array}{c}\text { Breast } \\
\text { cancer }\end{array}$ & $\mathrm{n}$ & 72 & 8 & 80 & & \\
\cline { 2 - 5 } & $\%$ & 90.0 & 10.0 & 100.0 & & \\
\hline
\end{tabular}

\subsubsection{Amplification}

Amplification is performed with a Rotor-Gene Q (Hilden, Germany) device.

* Detection on Fam (Green), Joe (Yellow)/Hex, Rox (Orange) and Cy5 (Red)

\subsubsection{Data Analysis \& Results Interpretation:}

Signal in a tube in the channel is considered to be positive, if corresponding fluorescence accumulation curves cross the threshold line. The signal is characterized by the cycle (threshold $\mathrm{Ct}$ ) corresponding to the intersection of the fluorescence curve with the threshold line. The softeare of analysis determines the $\mathrm{Ct}$ value. For quantitative analysis, the calibration curve is automatically plotted on the basis of these values, and human DNA and HPV DNA concentrations are calculated. To obtain the final result, HPV DNA concentration is normalized to the number of human genome equivalents according to the formula (see program Microsoft $\AA$ Excel "HPV Genotype 14 Real-TM.xls"):

$\log \left(\frac{\text { HPV DNA copies } / \text { reaction }}{\text { genomic DNA copies } / \text { reaction }} \times 200000\right)=\log ($ HPV DNA in 100000 cells $)$

\subsection{Data Analysis}

In order to analyze the data obtained from the study SPSS 16.0 (Statistical Package for Social Sciences) Package Program was used. Percentage distribution and numbers were given as a descriptive statistics. Chi-square test (Cross tabs-Chi Square test) was applied to analyze the data and the obtained results were evaluated at significance level of $95 \%$.

\section{Results}

\subsection{Demographic Findings of Patients}

A total of 93 patients were evaluated during the study and the demographic findings related to the disease are given below.

Patients between the ages of 27 and 86 were included in the study and the average age of patients included in the study was $51,63 \pm 12,217$ (Table 1)

Table 1. Average age of patients

\begin{tabular}{|c|c|c|c|c|c|}
\hline & $\mathrm{N}$ & Minimum & Maximum & $\begin{array}{c}\text { Average } \\
\text { rate }\end{array}$ & ss $( \pm)$ \\
\hline Age & 93 & 27 & 86 & 51,63 & 12,217 \\
\hline
\end{tabular}

Distribution of patients according to cancer types is seen in the table below. The majority of patients $(75.3 \%)$ were breast-invasive ductal cancer patients while $10.8 \%$ were breast-invasive lobular cancers and $14 \%$ were cervical cancer patients (Table 2).

(Table 3) shows the results obtained when the HR-HPV-DNA positivity was evaluated according to the cancer type. There was a significant difference in HR-HPV-DNA positivity according to the cancer type (p $<0.05$ ). As a result of our study, HR-HPV-DNA was positive in only 8 of the breast cancer samples $(10.0 \%)$ while was positive in 12 of 13 cervical cancer samples $(90 \%)$. 
Also HPV-DNA positivity was detected in 5 (7.1\%) of 70 patients with breast-invasive ductal carcinoma while in $3(30.0 \%)$ of 10 patients with breast-invasive lobular carcinoma, so there was a significant difference between groups according to pathological status of breast cancer $(\mathrm{p}<0.05)$ (Table 4).

The analysis conducted to determine whether the YR-HPV-DNA positivity was different according to the age of individuals included in the study revealed that YR-HPV-DNA positivity was detected in 1 of $36(2.8 \%)$ patients aged 50 or less and in $7(15.9 \%)$ of 44 patients aged 50 or older. Thus there was a significant difference between the groups $(\mathrm{p}<0.05)$ (Table 5).

According to the findings shown in (Table 6), HR-HPV-DNA was detected in 12 of 13 cases $(92.3 \%)$ of cervical cancer. HPV type 16 was the most common genotype $6 / 12$ of positive cervical cancer cases, and the prevalence of HPV (18-39-58), (33-35-56-68) types in the positive cervical cancer samples were $2 / 12$, and $1 / 12$ respectively. While HPV (45-56-68) types were the most common genotypes 4/8, HPV 39 type was detected in 2 of 8 and HPV (18-33-59) types in 1 of the 8 positive breast cancer cases.

As a result of our study, HPV type (56-68) were the most common genotypes $3 / 5$ of positive breast invasive ductal carcinoma samples while HPV type (45) was 2/3 of positive breast invasive lobular carcinoma samples (Table 7.)

The findings in (Table 8) obtained in our study revealed the frequency of single infection of HPV genotypes was
$9 / 12(75 \%)$ of positive cervical cancer samples. On the other hand, in the results shown in (Table 9), HPV co-infection frequency with multiple HPV genotypes was detected as $6 / 8(75 \%)$ of positive breast cancerous tissue samples.

Table 4. Comparison of HR-HPV DNA positivity according to pathological status of breast cancer

\begin{tabular}{|c|c|c|c|c|c|c|}
\hline \multicolumn{2}{|c|}{$\begin{array}{c}\text { pathological } \\
\text { status of } \\
\text { breast cancer }\end{array}$} & \multicolumn{2}{|c|}{ HR-HPV-DNA } & \multirow{2}{*}{ Total } & \multirow{2}{*}{$\chi^{2}$} & P \\
\cline { 2 - 5 } & Negatif & Pozitif & & \\
\cline { 1 - 4 } $\begin{array}{c}\text { Breast } \\
\text { invasive } \\
\text { ductal } \\
\text { cancer }\end{array}$ & $\mathrm{n}$ & 65 & 5 & 70 & & \\
\cline { 2 - 5 } & $\%$ & 92.9 & 7.1 & 100.0 & \multirow{2}{*}{5.887} & 0.015 \\
\cline { 1 - 5 } $\begin{array}{c}\text { Breast } \\
\text { invasive } \\
\text { lobular } \\
\text { cancer }\end{array}$ & $\mathrm{n}$ & 7 & 3 & 10 & & \\
\cline { 2 - 5 } & 70.0 & 30.0 & 100.0 & & \\
\hline
\end{tabular}

Table 5. Comparison of HR-HPV DNA positivity in breast cancer by age groups

\begin{tabular}{|c|c|c|c|c|c|c|}
\hline \multirow[b]{2}{*}{ Ag } & & \multicolumn{2}{|c|}{ HR-HPV-DNA } & \multirow{2}{*}{ Total } & \multirow{2}{*}{$\chi^{2}$} & \multirow{2}{*}{$\mathbf{P}$} \\
\hline & & Negative & Positive & & & \\
\hline \multirow[t]{2}{*}{$<=50$} & $\mathrm{n}$ & 35 & 1 & 36 & \multirow{4}{*}{3.970} & \multirow{4}{*}{0.046} \\
\hline & $\%$ & 97.2 & 2.8 & 100.0 & & \\
\hline \multirow[t]{2}{*}{$>50$} & $\mathrm{n}$ & 37 & 7 & 44 & & \\
\hline & $\%$ & 84.1 & 15.9 & 100.0 & & \\
\hline
\end{tabular}

Table 6. Prevalence and type distribution of HR-HPV genotypes in cervical and breast cancerous tissue specimens (-) Negative results

\begin{tabular}{|c|c|c|c|c|c|c|c|c|c|c|c|c|c|c|c|}
\hline \multirow{2}{*}{ Cancer type } & \multirow{2}{*}{$\begin{array}{c}\text { positive number of cases } \\
\text { (n) }\end{array}$} & \multicolumn{14}{|c|}{ HR-HPV genotypes } \\
\hline & & 16 & 18 & 31 & 33 & 35 & 39 & 45 & 51 & 52 & 56 & 58 & 59 & 66 & 68 \\
\hline $\begin{array}{c}\text { Cervical } \\
\text { cancer }\end{array}$ & 12 & 6 & 2 & - & 1 & 1 & 2 & - & - & - & 1 & 2 & - & - & 1 \\
\hline Breast cancer & 8 & - & 1 & - & 1 & - & 2 & 4 & - & - & 4 & - & 1 & - & 4 \\
\hline
\end{tabular}

Table 7. Prevalence and type distribution of HR-HPV genotypes in breast lobular and ductal cancerous tissue samples (-) Negative results

\begin{tabular}{|c|c|c|}
\hline \multirow{2}{*}{ HR-HPV genotypes } & \multicolumn{2}{|c|}{ Pathological status of breast cancer } \\
\cline { 2 - 3 } & Breast invasive ductal cancer & Breast invasive lobular carcinoma \\
\cline { 2 - 3 } & $\mathrm{n} /$ positive number of cases & $\mathrm{n} /$ positive number of cases \\
\hline 16 & - & - \\
\hline 18 & $1 / 5$ & - \\
\hline 31 & - & $1 / 3$ \\
\hline 33 & - & - \\
\hline 35 & - & $1 / 3$ \\
\hline 39 & $1 / 5$ & $2 / 3$ \\
\hline 45 & $2 / 5$ & - \\
\hline 51 & - & - \\
\hline 52 & - & $1 / 3$ \\
\hline 56 & $3 / 5$ & - \\
\hline 58 & - & $1 / 3$ \\
\hline 59 & - & - \\
\hline 66 & - & $1 / 3$ \\
\hline 68 & $3 / 5$ & \\
\hline
\end{tabular}


Table 8. Frequency of HR-HPV co-infection with multiple HPV genotypes in positive cervical cancerous tissue samples

\begin{tabular}{|c|c|c|c|c|c|}
\hline \multicolumn{2}{|c|}{ Single type } & \multicolumn{2}{c|}{ Multi- 2 types } & \multicolumn{2}{c|}{ Multi - 3 types } \\
\hline $\begin{array}{c}\mathrm{n} / \\
\text { positive } \\
\text { number } \\
\text { of cases }\end{array}$ & $\begin{array}{c}\text { HPV } \\
\text { type }\end{array}$ & $\begin{array}{c}\mathrm{n} / \\
\text { positive } \\
\text { number } \\
\text { of cases }\end{array}$ & $\begin{array}{c}\text { HPV } \\
\text { type }\end{array}$ & $\begin{array}{c}\mathrm{n} / / \\
\text { positive } \\
\text { number } \\
\text { of cases }\end{array}$ & HPV type \\
\hline $5 / 12$ & 16 & $1 / 12$ & $16-18$ & $1 / 12$ & $39-56-68$ \\
\hline $1 / 12$ & 18 & $1 / 12$ & $35-58$ & & \\
\hline $1 / 12$ & 33 & & & & \\
\hline $1 / 12$ & 39 & & & & \\
\hline $1 / 12$ & 58 & & & & \\
\hline
\end{tabular}

Table 9. Frequency of HR-HPV co-infection with multiple HPV genotypes in positive breast cancerous tissue samples

\begin{tabular}{|c|c|c|c|c|c|}
\hline \multicolumn{2}{|c|}{ Single type } & \multicolumn{2}{c|}{ Multi-2 types } & \multicolumn{2}{c|}{ Multi-3 types } \\
\hline $\begin{array}{c}\text { n/positive } \\
\text { number } \\
\text { of cases }\end{array}$ & $\begin{array}{c}\text { HPV } \\
\text { type }\end{array}$ & $\begin{array}{c}\mathrm{n} / \\
\text { positive } \\
\text { number } \\
\text { of } \\
\text { cases }\end{array}$ & $\begin{array}{c}\text { HPV } \\
\text { type }\end{array}$ & $\begin{array}{c}\mathrm{n} / \\
\text { positive } \\
\text { number } \\
\text { of cases }\end{array}$ & $\begin{array}{c}\text { HPV } \\
\text { type }\end{array}$ \\
\hline $1 / 8$ & 18 & $1 / 8$ & $39-45$ & $1 / 8$ & $45-56-68$ \\
\hline $1 / 8$ & 39 & $2 / 8$ & $56-68$ & $2 / 8$ & $33-45-59$ \\
\hline
\end{tabular}

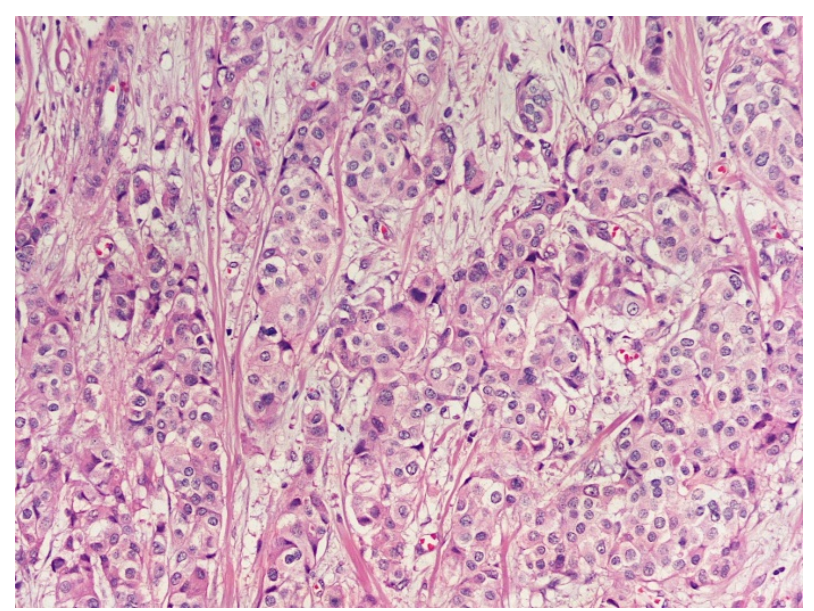

Figure 1. Histology shows small nests of pleomorphic tumor cells with rare tubular formation of $\mathrm{HPV}$-associated invasive ductal carcinoma, (H\&Ex200).

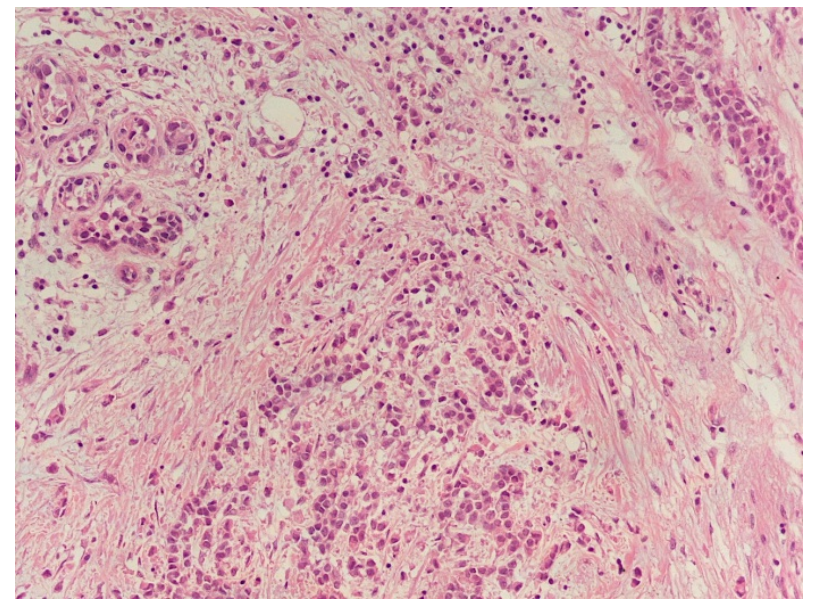

Figure 2. Histology shows small, round and uniform tumoral cells with minimal pleomorphism that grow in single file, linear pattern of HPV-associated invasive lobular carcinoma, (H\&Ex200)

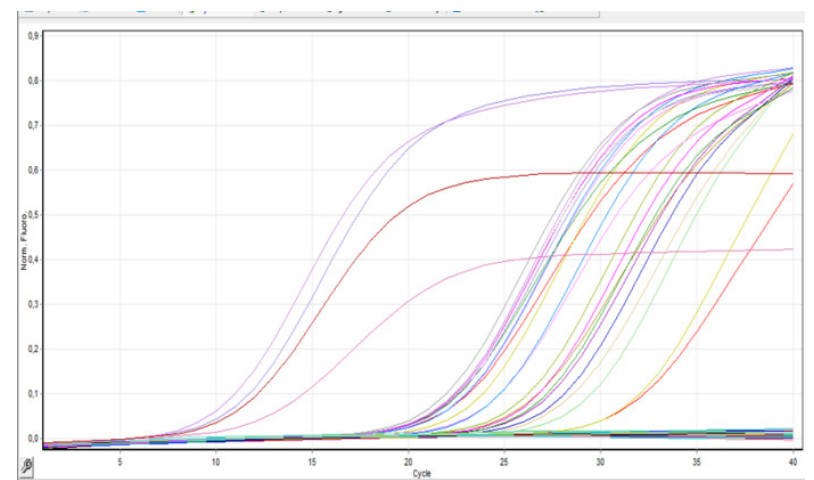

Figure. 3. Quantitative Real time PCR to detect the presence of HPV infection in tumour tissue DNA of cervical cancer patients.

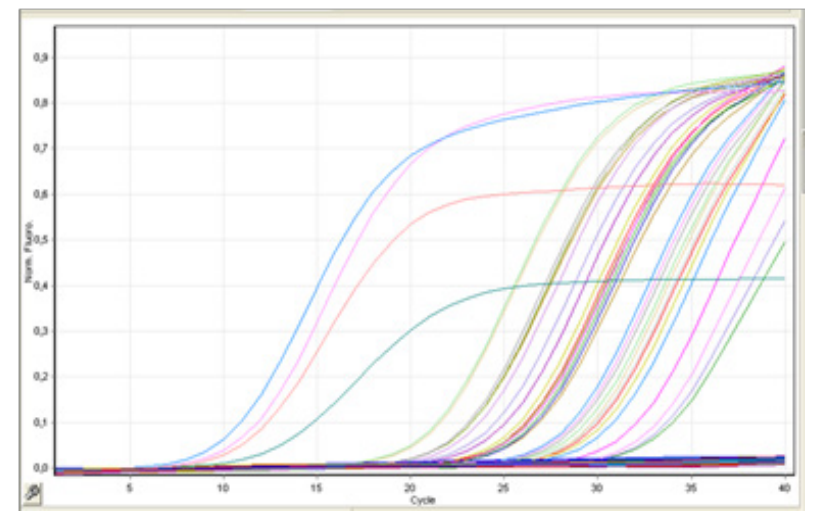

Figure 4. Quantitative Real time PCR to detect the presence of HPV infection in tumour tissue DNA of breast cancer patients

\section{Discussion}

Breast and cervical cancer is an important cause of death caused by cancer in women all over the world [16]. The global burden of breast cancer in women is markedly increasing. Breast cancer is the leading cause of cancer death among women worldwide. This emphasises the importance of identifying novel etiological risk factors that are associated with breast cancer development. Biological carcinogens such as viral infections play a significant role in cancer initiation since they contribute to approximately $18-20 \%$ of cancers [17]. The development of molecular techniques and subsequent investigations, have shown that HPV infection can cause lesions in the oral cavity, the anogenital region and the upper gastrointestinal tract [18]. HPVs are mucotrophic viruses and have specific characteristics which involved in the etiology of many cancers. To date, HPV has been associated with cancer in organs contaminated with direct contact (oropharyngeal region, genital organs, skin, etc) [19]. The lifecycle, oncogenic characteristics and molecular based evidence of HR-HPV suggest the causal role of breast cancer [20]. However, this hypothesis is quite controversial. Since the previous studies have reported that prevalence of HPV DNA ranges from $0 \%$ to $86.21 \%$ in breast cancer cells $[20,21]$. 
A number of studies have investigated HR-HPV in breast cancer in which the detection of the HPV infection was based on testing for the presence of viral DNA using range of molecular methods [17]. In PCR-based studies, HPV has not been encountered mainly. However, in 2009, two Australian studies claimed that they found an association between HPV and breast cancer with koilocyte presence by PCR-based methods [22, 23]. Although it is said that there is no HPV viremia, the hypothesis that HPV may be associated with other types of cancer as well as proven HPV- related cancers is a question that needs to be proven. This study was conducted to investigate the relationship between breast cancer and HPV.

Table 10. List of studies that identified HPV DNA sequences in breast cancer tissues

\begin{tabular}{|c|c|c|c|}
\hline Study report & $\begin{array}{l}\text { Number of } \\
\text { samples }\end{array}$ & $\begin{array}{c}\text { Total } \\
\text { HPVpositivit } \\
\text { y n }(\%)\end{array}$ & Country \\
\hline $\begin{array}{c}\text { Di Lonardo et al., } \\
1992[24]\end{array}$ & 70 & $7(10)$ & Italy \\
\hline $\begin{array}{c}\text { Henning et al., } \\
1999 \text { [25] }\end{array}$ & 41 & $19(46.3)$ & Sweden \\
\hline Yu et al., 1999 [26] & 72 & $19(26.3)$ & China \\
\hline Yu et al., 2000 [27] & 32 & $14(43.8)$ & China \\
\hline Liu et al, 2004 [28] & 17 & $6(35)$ & China \\
\hline $\begin{array}{l}\text { Damin et al., } \\
2004 \text { [29] }\end{array}$ & 101 & $25(24.7)$ & Brazil \\
\hline $\begin{array}{l}\text { Widschwendter et } \\
\text { al.,2004 [30] }\end{array}$ & 11 & $7(63.7)$ & Austria \\
\hline $\begin{array}{l}\text { de Villiers et al., } \\
2005[20]\end{array}$ & 29 & $25(86.2)$ & USA \\
\hline $\begin{array}{c}\text { Kroupis et al., } \\
2006[31]\end{array}$ & 107 & $17(15.9)$ & Greece \\
\hline Kan et al., 2005 [32] & 50 & $24(48)$ & Australia \\
\hline $\begin{array}{c}\text { Gumus et al., } \\
2006[33]\end{array}$ & 50 & $37(74)$ & Turkey \\
\hline $\begin{array}{c}\text { Khan et al., } 2008 \\
{[34]}\end{array}$ & 124 & $26(20.9)$ & Japan \\
\hline $\begin{array}{c}\text { Akil, N. et al. } \\
2008 \text { [7] }\end{array}$ & 113 & $69(61.06)$ & Syria \\
\hline $\begin{array}{c}\text { de Leon et al., } \\
2009 \text { [35] }\end{array}$ & 51 & $15(29.5)$ & Mexico \\
\hline $\begin{array}{l}\text { Mendizabal-Ruiz et } \\
\text { al., 2009 [36] }\end{array}$ & 67 & $3(4.4)$ & Mexico \\
\hline $\begin{array}{c}\text { Heng et al., } \\
2009 \text { [22] }\end{array}$ & $\begin{array}{l}26 \text { biopsies } \\
9 \text { cell lines }\end{array}$ & $\begin{array}{c}8(30.7) \\
2(22) \\
\end{array}$ & Australia \\
\hline $\begin{array}{c}\text { Salman, N. A. et al. } \\
2017 \text { [17] }\end{array}$ & 74 & $35(47)$ & UK \\
\hline $\begin{array}{c}\text { Silvia } \\
\text { Delgado-García.et } \\
\text { al. } 2017 \text { [1] }\end{array}$ & 251 & $130(51.8)$ & Spain \\
\hline
\end{tabular}

Our data also showed the presence of 7 HR-HPV DNA genotypes in $8 / 80(10 \%)$ of breast carcinoma cases. The results obtained in our study were consistent with the findings of other studies in different geographical regions worldwide, which reported that there was low frequency (\% $4-15.9)$ of human papillomavirus DNA in breast cancer tissue. While a moderate (20-48\%) to high frequency $(60-86.2 \%)$ of HPV infection has been reported by many researches (Table 10). Conversely, some studies have reported that there was no HPV infection in breast cancer (Table 11).

Table 11. List of studies that did not detect HPV DNA sequences in breast cancer tissues

\begin{tabular}{|c|c|c|c|}
\hline Study report & $\begin{array}{c}\text { Number } \\
\text { of sampl } \\
\text { es }\end{array}$ & $\begin{array}{c}\text { Total } \\
\text { HPVpositivit } \\
\text { y n (\%) }\end{array}$ & Country \\
\hline $\begin{array}{c}\text { Wrede et al., } \\
1992 \quad[37]\end{array}$ & 92 & 0 & UK \\
\hline $\begin{array}{c}\text { Bratthauer et al., } \\
1992[38]\end{array}$ & 43 & 0 & USA \\
\hline $\begin{array}{c}\text { Gopalkrishna et al., } \\
1996 \text { [39] }\end{array}$ & 30 & 0 & India \\
\hline $\begin{array}{c}\text { Czerwenka et al., } \\
1996 \quad[40]\end{array}$ & 20 & 0 & Austria \\
\hline $\begin{array}{c}\text { Lindel et al., 2007 } \\
{[41]}\end{array}$ & 81 & 0 & Switzerland \\
\hline $\begin{array}{c}\text { de Cremoux et } \\
\text { al.,2008 [42] }\end{array}$ & 50 & 0 & France \\
\hline $\begin{array}{c}\text { Hedau et al. 2011 } \\
\text { [43] }\end{array}$ & 252 & 0 & India \\
\hline
\end{tabular}

Earlier studies on breast cancer have reported that HPV types 11, 16 and 18 are the most frequent in women living in the United States and Brazil [28,29]; and HPV type 18 is present in the majority of Australian women [32]. In parallel, HPV type 33 is the most frequent virus in Asian women [26, 27]. HPV type 16 has been identified in Italian and Norwegian women who had previous cervical neoplasias [25]. Moreover, we recently reported that HPV type 16 is the only type present in Canadian women. However, studies on the presence of high-risk HPV in the Middle East reveal that HPV types 18, 33 and 35 are present in breast cancer and normal mammary tissues in Turkish women [33]. On the other hand, as an endeavor to determine the possible origin of HPV in the breast, a number of researchers $[25,30,44,45]$ have investigated the potential relationship between presence of this virus in the breast and cervical disease associated with HPV. On the basis of their studies it is not possible to conclude that HPV of the breast originates from the cervix. This seems to be consistent with our results below.

In our study, although HPV type 16 was the prevalent virus of the high-risk HPV family in cervical cancer tissue, it was not common in breast cancer tissue. Our data revealed the most prevalent HPV types detected in HPV-associated breast cancer samples were HPV 45, 56 and 68 in $4(50 \%)$, followed by HPV 39 in $2(25 \%)$, and each of HPV type 18, 33 and 59 in 1(12.5\%) of positive samples.

Unlike our study, a number of reports have identified HPV types 16 and 18 as most prevalent types in breast cancer tissues, but these relied on screening a limited number of HR-HPV types [46]. This in turn limited the detection of many other HR HPV genotypes that have been identified in our study. 
In addition, the examination of 14 different high-risk HPV types for each one of breast specimens allowed to detect HR-HPVs co-infection in 6/8 $(75 \%)$ of positive cancerous samples. This was significantly higher compared with the rate of HR-HPVs co-infection in cervical cancer where it was $3 / 12$ $(\% 25)$ of positive cases.

Multiple HR-HPV infections may interact or act synergistically to stimulate cancer development or could possibly lead to increase the risk of breast cancer progression in the presence of other cofactors. This observation may possibly explain the aetiology behind the detection of multiple HPV in the pathogenesis of breast cancer.

In a study conducted by B. Heng et al (22) in Australia indicated to the observation that HPV type 18 was by far the most common type in these Australian breast cancers is meaningful as most breast cancers can be regarded as originating from breast-milk epithelial cells (despite the historically misleading terminology of 'ductal' breast carcinomas). Therefore, most breast cancers are 'glandular'. HPV type 18 has an affinity or tropism to glandular as compared with squamous epithelial cells [47].

Our data also revealed that the prevalence of HPV DNA in cancerous cases was higher among women with lobular invasive carcinoma than in women with ductal carcinoma.

Evidence shows that the addition of HPV type 45 identifies more women at risk for adenocarcinoma with minimal impact to colposcopy rates. HPV type 45 associated with $12 \%$ of adenocarcinomas [48].

In our study HPV type (45) was present in 2 of the 3 HPV-associated breast invasive lobular carcinoma samples. Our data revealed to be consistent with the literature.

\section{Conclusions}

In conclusion, we demonstrated that there was low frequency $(10 \%)$ of high-risk HPV prevalence in invasive breast cancer in Turkish women. In addition, HPV 45, 56 and 68 types were the most dominant types in breast cancer and the HPV co-infection was high (75\%) in positive breast cancer tissue samples. Our data propose Human papilloma viruses may play a role as a possible causal relationship, or mediation or even as a cofactor in the development of some types of breast cancer. However the low frequency of HPV in breast cancer tissue of Turkish women in our study emphasizes the importance of further studies to better understand, investigate and evaluate the potential role of HPV in the development of breast cancer.

\section{REFERENCES}

[1] Silvia Delgado-Garcíal et al. Presence of human papillomavirus DNA in breast cancer: a Spanish case-control study Delgado-García et al. BMC Cancer (2017) 17:320 DOI 10.1186/s12885-017-3308-3

[2] Nebahat Özerdoğan et al.Educational Study to Increase Breast Cancer Knowledge Level and Scanning Participation among Women Working at a University Eur J Breast Health. 2017 Jul; 13(3): 113-116.

[3] http://eprints.kingston.ac.uk/37706/1/Ashrafi-G-H-37706VoR.pdf.

[4] Band V, Zajchowski D, Kulesa V, Sager R. Human papillomavirus DNAs immortalize normal human mammary epithelial cells and reduce their growth factor requirements. Proc Natl Acad Sci U S A 1990; 87: 463-7.

[5] Chang, F. Et al. Detection of human papillomavirus DNA in cytologic specimens derived from esophageal precancer lesions and cancer. Scand J Gastroenterol 25, 383 -388 (1990).

[6] Jenson, A. B., Geyer, S., Sundberg, J. P. \& Ghim, S. Human papillomavirus and skin cancer. J Investig Dermatol Symp Proc 6, 203-206 (2001)

[7] Akil, N. Et al. Human breast cancer and sexual activities. Br J Cancer 98, 508-509 (2008).

[8] Haghshenas, M. Et al. Prevalence and type distribution of high-risk human papillomavirus in patients with cervical cancer: a population-based study. Infect Agent Cancer 8, 20, doi: 10.1186/1750-9378-8-20 (2013).

[9] Hernandez, B. Y. et al. Transmission of human papillomavirus in heterosexual couples. Emerg Infect Dis 14, 888-894 (2008).

[10] Ohba, K. Et al. In vivo and in vitro studies suggest a possible involvement of HPV infection in the early stage of breast carcinogenesis via APOBEC3B induction. PLoS One 9, doi: 10.1371/journal.pone.0097787 (2014).

[11] Begum S, Gillison ML, Ansari-Lari MA, Shah K, Westra WH (2003) Detection of human papillomavirus in cervical lymph nodes: a highly effective strategy for localizing site of tumor origin. Clin Cancer Res 9: 6469-6475

[12] Graflund M, Sorbe B, Sigurdardottir S, Karlsson M (2004) HPV-DNA, vascular space invasion, and their impact on the clinical outcome in early-stage cervical carcinomas. Int $\mathbf{J}$ Gynecol Cancer 14: 896-902

[13] Varnai AD, Bollmann M, Griefingholt $H$, Speich $N$, Schmitt C, Bollmann R, Decker D (2006) HPV in anal squamous cell carcinoma and anal intraepithelial neoplasia (AIN).Impact of HPV analysis of anal lesions on diagnosis and prognosis. Int J Colorectal Dis 21: 135-142

[14] Vousden KH (1995) Regulation of the cell cycle by viral oncoproteins. Semin Cancer Biol 6: 109-116

[15] Polyak, K. Breast cancer: origins and evolution. J Clin Invest 117, 3155-3163 (2007). 
[16] Hasene Özçam, Gönül Çimen, Cihangir Uzunçakmak, Selvi Aydın, Tuba Özcan, Birtan Boran. Kadın Sağlık Çalışanlarının Meme Kanseri, Serviks Kanseri ve Rutin Tarama Testlerini Yaptırmaya İlişkin Bilgi Tutum ve Davranışlarının Değerlendirilmesi, İstanbul Med J 2014; 15: 154-60 DOI: 10.5152/imj.2014.86548.

[17] Salman, N. A. et al. Association of High Risk Human Papillomavirus and Breast cancer: A UK based Study. Sci. Rep. 7, 43591; doi: 10.1038/srep43591 (2017).

[18] zur Hausen H. Papillomaviruses in the causation of human cancers a brief historical account. Virology 2009; 384: 2605.

[19] Gillison ML, Shah KV. Chapter 9: Role of mucosal human papillomavirus in nongenital cancers. J Natl Cancer Inst Monogr. 2003; (31):5765

[20] De Villiers E,Sandstrom RE, Zur Hausen H, Buck CE. Presence of papillomavirus sequences in condylomatous lesions of the mamillae and in invasive carcinoma of the breast. Breast Cancer Res. 2005; 7(1):R1-11.

[21] Joshi D, Buehring GC. Are viruses associated with human breast cancer? Scrutinizing the molecular evidence. Breast Cancer Res Treat. 2012; 135(1):1-15.

[22] Heng B, Glenn WK, Ye Y, Tran B, Delprado W, Lutze-Mann L, Whitaker NJ, Lawson JS: Human papilloma virus is associated with breast cancer. British Journal of Cancer 2009, 101:1345-1350.

[23] Lawson JS, Glenn WK, Heng B, Ye Y, Tran B, LutzeMann L, Whitaker NJ. Koilocytes indicate a role for human papilloma virus in breast cancer. Br J Cancer. 2009 Oct 20; 101(8):13516.

[24] 26. Di Lonardo A, Venuti A, Marcante ML: Human papillomavirus in breast cancer. Breast Cancer Res Treat 1992, 21:95-100.

[25] Hennig EM, Suo Z, Thoresen S, Holm R, Kvinnsland S, Nesland JM: Human papillomavirus 16 in breast cancer of women treated for high grade cervical intraepithelial neoplasia (CIN III). Breast Cancer Res Treat 1999, 53(2):121-135.

[26] Yu Y, Morimoto T, Sasa M, Okazaki K, Harada Y, Fujiwara T, Irie Y, Takahashi E, Tanigami A, Izumi K: Human papillomavirus type 33 DNA in breast cancer in Chinese. Breast Cancer 2000, 7(1):33-36.

[27] Yu Y, Morimoto T, Sasa M, Okazaki K, Harada Y, Fujiwara T, Irie Y, Takahashi E, Tanigami A, Izumi K: HPV33 DNA in premalignant and malignant breast lesions in Chinese and Japanese populations. Anticancer Res 1999, 19(6B):5057-5061.

[28] Liu Y, Klimberg VS, Andrews NR, Hicks CR, Peng H, Chiriva-Internati M, Henry-Tollman R, Hermonat PL: Human papillomavirus DNA is present in a subset of unselected breast cancers. J Hum Virol 2001, 4(6):329-334.

[29] Damin AP, Karam R, Zettler CG, Caleffi M, Alexandre CO: Evidence for an association of human papillomavirus and breast carcinomas. Breast Cancer Res Treat 2004, 84(2):131-137.

[30] Widschwendter A, Brunhuber T, Wiedemair A, Mueller-Holzner E, Marth C: Detection of human papillomavirus DNA in breast cancer of patients with cervical cancer history. J Clin Virol 2004, 31(4):292-297.

[31] 33. Kroupis C, Markou A, Vourlidis N, Dionvssiou-Asteriou A, Lianidou ES: Presence of high-risk human papillomavirus sequences in breast cancer tissues and association with histopathological characteristics. Clin Biochem 2006, 39:727-731.

[32] Kan CY, Iacopetta BJ, Lawson JS, Whitaker NJ: Identification of human papillomavirus DNA gene sequences in human breast cancer. Br J Cancer 2005, 93 (8):946-948.

[33] Gumus M, Yumuk PF, Salepci T, Aliustaoglu M, Dane F, Ekenel M, Basaran G, Kaya H, Barisik N, Turhal NS: HPV DNA frequency and subset analysis in human breast cancer patients normal and tumoral tissue samples. J Exp Clin Cancer Res 2006, 25(4):515-521.

[34] Khan NA, Castillo A, Koriyama C, Kijima Y, Umekita Y, Ohi Y, Higashi M, Sagara Y, Yoshinaka H, Tsuji T, Natsugoe S, Douchi T, Eizuru Y, Akiba S: Human papillomavirus detected in female breast carcinomas in Japan. Br J Cancer 2008, 99 (3):408-414.ncer Res 2006, 25(4):515-521.

[35] de Leon DC, Montiel DP, Nemcova J, Mykyskova I, Turcios E, Villavicencio V, Cetina L, Coronel A, Hes O: Human papillomavirus (HPV) in breast tumors: prevalence in a group of Mexican patients. BMC Cancer 2009, 9:26.

[36] Mendizabal-Ruiz AP, Morales JA, Ramirez-Jirano LJ, Padilla-Rosas M, Moran- Moguel MC, Montoya-Fuentes H: Low frequency of human papillomavirus DNA in breast cancer tissue. Breast Cancer Res Treat 2009, 114:189-194.

[37] Wrede D, Luqmani YA, Coombes RC, Vousden KH: Absence of HPV16 and 18 DNA in breast cancer. Breast Cancer Research 1992, 65(6):891-4.

[38] Bratthauer GL, Tavassoli FA, O’Leary TJ: Etiology of breast carcinoma: no apparent role for papillomavirus types 6/11/16/18. Pathol Res Pract 1992, 188(3):384-6.

[39] Gopalkrishna V, Singh UR, Sodhani P, Sharma JK, Hedau ST, Mandal AK, Das BC: Absence of human papillomavirus DNA in breast cancer as revealed by polymerase chain reaction. Breast Cancer Res Treat 1996, 39(2):197-202.

[40] .Czerwenka K, Heuss F, Hosmann JW, Manavi M, Lu Y, Jelincic D, Kubista E: Human papillomavirus DNA: a factor in the pathogenesis of mammary Paget's disease? Breast Cancer Res Treat 1996, 41:51-57.

[41] .Lindel K, Forster A, Altermatt HJ, Greiner R, Gruber G: Breast cancer and human papillomavirus (HPV) infection: no evidence of a viral etiology in a group of Swiss women. Breast 2007, 16:172-177.

[42] de Cremoux P, Thioux M, Lebigot I, Sigal-Zafrani B, Salmon R, Sastre- Garau X: No evidence of human papillomavirus DNA sequences in invasive breast carcinoma. Breast Cancer Res Treat 2008, 109:55-58.

[43] Hedau et al.: Breast cancer and human papillomavirus infection: No evidence of HPV etiology of breast cancer in Indian women. BMC Cancer 2011 11:27.

[44] Hansen B, Nygård M, Falk R, Hofvind S. Breast cancer and 
ductal carcinoma in situ among women with prior squamous or glandular precancer in the cervix: a register based study. Br J Cancer. 2012; 107(9):1451-3.

[45] Lv YR, Wang JL, Zhang K, Gao HD, Sun JZ, Gong YY, et al. Human papillomaviruses (HPVs) no co-existence in breast cancer and cervical cells in the same patient. Chin $\mathrm{J}$ Physiol. 2014; 57(2):105-6.

[46] . Li, N. et al. Human papillomavirus infection and sporadic breast carcinoma risk: a meta-analysis. Breast Cancer Res
Treat 126, 515-520 (2011).

[47] Clifford G, Franceschi S. 2008. Members of the human papillomavirus type 18 family (alpha-7 species) share a common association with adenocarcinoma of the cervix. Int. J. Cancer 122:1684-1685. 10.1002/ijc.23282.

[48] de Sanjose S, Quint WG, Alemany L, et al. Human papillomavirus genotype attribution in invasive cervical cancer: a retrospective cross-sectional worldwide study. Lancet Oncol. 2010; 11(11):1045-1056. 